\title{
Tourists' Satisfaction on Penang Hawker Centres, Malaysia
}

\author{
Dr. Krishna Moorthy*, Ms Loh Chun T'ing, Mr. Ong Zhan Hao, Mr. Chong Kim Seong, Ms. Emylia Cheong Ai \\ Lin, Ms. Teoh Yoon Chee, Mr.Yong Chee Min \\ Faculty of Business and Finance, Universiti Tunku Abdul Rahman, Kampar Campus, Perak, Malaysia
}

\section{*Corresponding Author}

Dr. Krishna Moorthy

\section{Article History}

Received: 06.08.2019

Accepted: 27.08 .2019

Published: 30.08 .2019

\begin{abstract}
The objective of this study is to identify the factors that affect satisfaction of Penang tourists who patronize Penang hawker centres by combining SERVQUAL model with food quality. The collected data from 259 tourists was analyzed and hypotheses were tested by using Multiple Linear Regression (MLR) analysis. Result of this study shows that food quality and service qualities (reliability and assurance) have a significant positive relationship with customer satisfaction. In terms of theoretical significance, this study proved that food quality has greater significant positive relationship with customer satisfaction than service quality. The combination of SERVQUAL model and food quality in testing the customer satisfaction has been validated in this study. The Penang State Government should emphasize on improving the quality of Penang street foods during policy setting process. The findings of this study are applicable to any hawker centre globally to improve the quality of the food.
\end{abstract}

Keywords: Customer Satisfaction, Service Quality, Food Quality, Hawker Centre, Tourist, Culinary Tourism.

\section{INTRODUCTION}

Out of the whole Malaysia, Penang is the best culinary destination to travel as it was recognized by the CNN as one of the top ten street food cities in Asia [1]. Penang was recognized by the Time Magazine as having the best street foods in Asia [2]. The number of international visitors of Penang had grown dramatically by $60.2 \%$ from 448,000 arrivals in 2007 to 718,000 arrivals in 2014 [3]. As the street foods are playing an essential role towards Penang tourism sector, this research has been conducted with the general objective of identifying the attributes influencing the satisfaction level of Penang tourists. Specifically, this research aims to investigate whether the SERVQUAL variables (tangibles, reliability, responsiveness and assurance) and food quality affect the customer satisfaction. Service quality is taken into consideration to test the customer satisfaction because it is the main factor affecting customer satisfaction [4, 5]. Food quality also plays an important role in influencing customers' dining experience and their satisfaction $[6,7]$. Thus, food quality has also been taken as one of the influencing factors that affect customer satisfaction.

\section{Problem Statement and Research Gap}

Malaysia is facing an intense competition in the tourism sector with other Asian countries such as China, Thailand and Taiwan $[8,9]$. Moreover, there is a substantial increase in the number of street food vendors in the major Asian cities [10]. Thus, Penang gastronomy tourism sector has to strive for improvement by providing better food and service quality that can enhance the satisfaction level of tourists. However, there are only a few researches on Penang food services sector to be referred to [11, 12].

Various past studies had studied on how service quality affects customer satisfaction by applying SERVQUAL model [13, 14]. However, those past studies which studied on the food service sector rarely focused on hawker centres, but on restaurants [15, 12, 16]. Moreover, limited studies have addressed customer satisfaction by taking into consideration of the food quality, even though food quality is an essential variable that contributes to customer satisfaction $[17,7]$. Therefore, hawker centre is chosen as the area to conduct this study by combining SERVQUAL model with food quality in order to fill in the gap of attributes that affect the customer satisfaction in food service sector.

Copyright @ 2019: This is an open-access article distributed under the terms of the Creative Commons Attribution license which permits unrestricted use, distribution, and reproduction in any medium for non commercial use (NonCommercial, or CC-BY-NC) provided the original author and source are credited. 
In the past, there are many researches applied different models in investigating how service qualities influence customer satisfaction such as ACSI Model [4]; DINESERV model [18-20]; SERVPERF model [21, 22] and Restaurant Quality Attribute model [23].

Various past studies had also studied on how service quality affects customer satisfaction by applying SERVQUAL model $[13,14,24,25]$. However, some of the studies were not focusing on food service sector but other sectors such as mobile telecommunication sector [26, 5]; public transport sector [27, 28] and maritime sector [29].

Furthermore, the past studies conducted on the food service sector were rarely focused on hawker centres. They focused on restaurants such as chain restaurants [15]; cafes [12]; limited service restaurant [30] and quick-casual restaurants [16]. Therefore, hawker centre is chosen as the area to conduct this study in order to fill in the gap of how SERVQUAL attributes affect the customer satisfaction in food service sector.

On top of service quality, from the review of past studies, it has been found that food quality is also an essential factor that contributes to customer satisfaction [17, 31-33, 7]. However, no study has addressed customer satisfaction by taking into consideration of the SERVQUAL dimensions together with food quality. Thus, in this study, SERVQUAL dimensions are adapted to combine with food quality.

\section{Review of Relevant Theoretical Model}

SERVQUAL model was introduced in 1985 which explained how the service qualities affect customer satisfaction. Initially it contained 10 dimensions [34, 35]. However, this 10-dimensions SERVQUAL model was criticized by various researchers [36-38]. As some of the dimensions of SERVQUAL were auto-correlated, and the founders of SERVQUAL model had refined the model to consist of only 5 dimensions with 22 items $[39,40]$.

Subsequently, various studies have confirmed the 5-dimensions SERVQUAL model in different nations and different sectors $[41,42]$. In addition, numerous studies have adapted SERVQUAL model as a base to develop different models to measure services rendered in different areas as shown in Table-1 below.

Table-1: Models Developed Based on SERVQUAL

\begin{tabular}{|l|l|l|}
\hline \multicolumn{1}{|c|}{ Model } & \multicolumn{1}{|c|}{ Area of Service Provided } & \multicolumn{1}{c|}{ Source } \\
\hline HISTOQUAL & Historic houses for tourism industry & Frochot and Hughes (2000) [43] \\
\hline SITEQUAL & Online shopping & Yoo and Donthu (2001) [44] \\
\hline WebQual & Cyber bookshop business & Barnes and Vidgen (2001) [45] \\
\hline LibQUAL & Library & Cook, Heath, and Thompson (2001) [46] \\
\hline ECOSERV & Ecotourism & Khan (2003) [47] \\
\hline E-S-QUAL & Electronic service business & Parasuraman, Zeithaml, and Malhotra (2005) [48] \\
\hline LODGSERV & Hotel Services & Keith and Simmers (2013) [49] \\
\hline AIRQUAL & Airlines services & Ali, Dey, and Filieri (2015) [50] \\
\hline
\end{tabular}

\section{REVIEW OF LITERATURE \\ Customer Satisfaction}

Customer satisfaction is defined by Parasuraman et al., [34] as an evaluative judgment made after the transaction. It was proved to have significant positive effect upon customer loyalty and customer retention [51, 52]. Not only that, various research results showed that satisfied customers tend to give positive word of mouth (WOM) in regard to the service provided [53]. According to Ara [54], customer satisfaction is significantly affected by service quality. Besides, food quality was also being proved as a fundamental variable affecting customer satisfaction in various literatures $[55,56]$.

\section{Tangibles and Customer Satisfaction}

According to Parasuraman et al., [35], tangibles are the physical appearance of the material, equipment or staff used in serving the customers. Even though the study of Kaura, Durga, and Sharma [57] showed that tangibles do not significantly impact customer satisfaction, many researches have concluded contrary $[58,59]$. In the context of hawker centres, the tangibles dimension refers to the cleanliness and appearance of the hawkers and hawker centre. If tangibles are in poor condition, tourists will definitely feel dissatisfied. Therefore, following hypothesis is proposed in this research.

$\mathrm{H}_{1}$ : There is a significant positive relationship between tangibles and customer satisfaction of Penang tourists who patronize Penang hawker centres. 


\section{Reliability and Customer Satisfaction}

Reliability is defined by Parasuraman et al., [35] as the promised services are able to be performed accurately and dependably. According to the research conducted by Yuen and Thai [29], reliability was proved as having the most significant impact on customer satisfaction among with other dimensions of SERVQUAL model. In addition, Dauda and Lee [60] and Teshome and Seyoum [61] found that reliability possess a positive and significant relationship with customer satisfaction. In terms of hawker centre, reliability is related to the hawkers' ability to serve customers in accordance with what have been requested and ordered. If the level of reliability is low, tourists will definitely feel dissatisfied with the service provided. Hence, the following hypothesis is formulated to analyze the impact of reliability on the satisfaction level of Penang tourists.

$\mathrm{H}_{2}$ : There is a significant positive relationship between reliability and customer satisfaction of Penang tourists who patronize Penang hawker centres.

\section{Responsiveness and Customer Satisfaction}

Responsiveness is referring to the willingness to provide quick service as well as help customers [35]. In the study of Shanka [62], responsiveness was proved as the dimension of SERVQUAL which has the most essential role in affecting customer satisfaction. Many past studies found that responsiveness is a variable that significantly and positively affects customer satisfaction $[63-65,14]$. In the context of hawker centre, responsiveness is about how fast and how good the hawkers deliver their service and food. If the hawkers are highly responsive to the customer requests, then the service provided is deemed to be satisfactory. Therefore, the following hypothesis is proposed.

$\mathrm{H}_{3}$ : There is a significant positive relationship between responsiveness and customer satisfaction of Penang tourists who patronize Penang hawker centres.

\section{Assurance and Customer Satisfaction}

Assurance is defined as the courtesy and knowledge of employees and their ability to inspire confidence and trust [35]. Based on the research of Omar, Ariffin, and Ahmad [66], assurance dimension of SERVQUAL has the most significant positive influence on the customer satisfaction. Moreover, the significant positive relationship between assurance and customer satisfaction is also confirmed by the study by Anjum, Aftab, Sultan and Ahmed [67]. In the context of hawker centre, if the hawkers are courteous, polite and friendly, the level of assurance can be concluded as high and it will delight the customers. Therefore, this study will put forward the following hypothesis to determine the effect of assurance on the satisfaction level of Penang tourists.

$\mathrm{H}_{4}$ : There is a significant positive relationship between assurance and customer satisfaction of Penang tourists who patronize Penang hawker centres.

\section{Food Quality and Customer Satisfaction}

According to Koo, Tao, and Yeung [68], taste is an essential element that constitutes food quality. Other than taste, food quality includes food cleanliness, food texture, food freshness and food temperature [69]. Additionally, Raajpoot [70] had conducted a study which stated that food quality can be measured by menu design, food presentation, variety of food and serving size. In the research of Ramanathan, $\mathrm{Di}$, and Ramanathan [71], food quality is proved as the factor correlated mostly with customer satisfaction. In addition, Hanaysha [72] found out that customer satisfaction is strongly influenced by the food quality. In the context of hawker centre, the tastiness and freshness of foods will definitely affect the customer dining experience and satisfaction. Jeong and Seo [73] suggested that foodservice managers should try to maximize food and service qualities for residents because improving food and service quality improves their quality of life. Customer well-being or happiness was driven by service quality [74]. Thus, in order to analyze the effect of hawker's food quality on the satisfaction level of Penang tourists, following hypothesis is formulated.

$\mathrm{H}_{5}$ : There is a significant positive relationship between food quality and customer satisfaction of Penang tourists who patronize Penang hawker centres.

Based on the above discussions, the following research model is proposed. 


\section{Proposed Research Model}

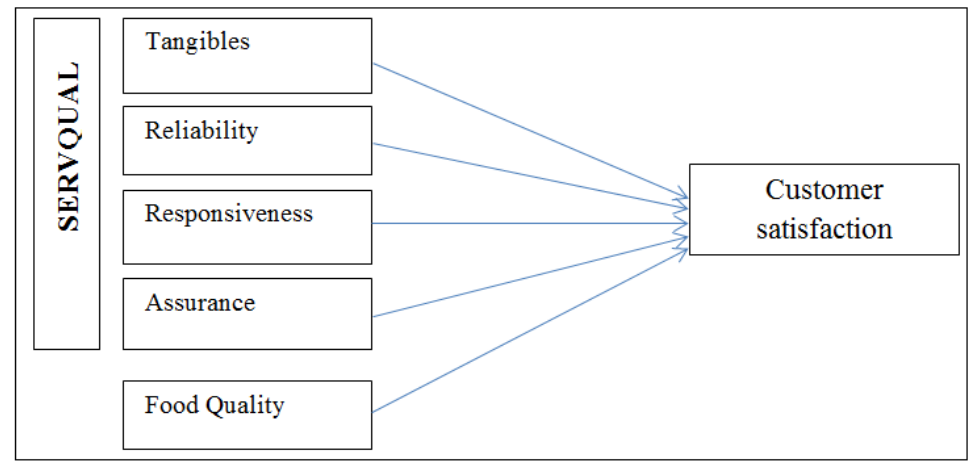

Fig-1: Proposed Research Model

Source: Parasuraman et al., (1991) [39] and Ryu, Lee, and Kim (2012) [75]

\section{Research Design}

A questionnaire survey was conducted in the form of quantitative, cross sectional study in order to investigate the tourists' perception towards their satisfaction level on food and service provided by Penang street food hawkers. This research utilized cross sectional approach instead of longitudinal survey because it enables complete information to be collected without waiting for a longer time period [76]. Besides, no follow-up is needed in cross-sectional research and therefore it consumes less resources, quicker and cheaper [77].

\section{Data Collection Method}

This research applied two types of data collection method, which are primary data and secondary data [78]. In this research, primary data was collected through questionnaire survey while secondary data was collected through journals, news articles and books from different sources [79].

\section{Research Instrument}

A self-administered questionnaire was used as an instrument to collect empirical data in several hawker centres located at Georgetown, Penang. This is because this data collection method could reach more target respondents in short time, assure high response rate, minimize biases and obtain honest answer because target respondents were allowed to be anonymous [80-82]. A pretest was conducted by consulting various experts in the area of TQM and the validity of the questionnaire was confirmed. Moreover, a pilot test had been conducted with 30 respondents to confirm the reliability of the questionnaire [83].

Table-2: Pilot Test for Questionnaire Reliability

\begin{tabular}{|l|c|}
\hline \multicolumn{1}{|c|}{ Variables } & Cronbach's Alpha Value \\
\hline Tangibles (T) & 0.7703 \\
\hline Reliability (R) & 0.8440 \\
\hline Responsiveness (RP) & 0.7956 \\
\hline Assurance (A) & 0.7904 \\
\hline Food Quality (FQ) & 0.8256 \\
\hline Customer Satisfaction (CS) & 0.8920 \\
\hline
\end{tabular}

Table-2 illustrates the result of the pilot test in which the Cronbach's alpha values for each of the variable ranged from 0.7703 to 0.8920 . Hence, the researchers concluded that this survey questionnaire is reliable as all the variables have exceeded the threshold Cronbach's alpha value 0.7 [84].

\section{Sampling Design}

Sampling instead of census was preferred in this study because it is impractical to survey the whole population of Penang tourists; thus sampling technique was applied, as it is able to represent the entire population [85]. Besides, sampling is less costly, less time-consuming and able to provide timely information as the data can be collected quicker [86].

\section{Target Population}

The population in this research is the tourists who patronize Penang hawker centres as they are the one who are able to give more accurate information regarding tourists' needs and wants. 


\section{Sampling Frame}

No sampling frame is available as the number of Penang tourists is huge and it is impossible to obtain the details of every Penang tourists, probability sampling technique is unfeasible in this research [87]. Due to this feasibility constraint, non-probability sampling is the most appropriate technique applied in this research [88].

\section{Sampling Technique}

Judgmental sampling technique was applied in this study by obtaining data from specific target respondents (Penang's tourists) as this technique is more efficient [89]. Furthermore, specific target respondents are able to provide more unique, relevant and valuable information to the research $[90,91]$.

\section{Sampling Size}

According to Hinkin [92], the recommended sample size should range from item-to-response ratio of 1:4 and to 1:10. Hence, the recommended sample size for this study ranged from 128 to 320 respondents. A total of 303 survey questionnaires were administered to the Penang's tourists who have consented to take part in this survey. However, only 259 sets of questionnaires are usable and had been employed in the analysis of this research. This sample size is considered to be appropriate and representative for the population in this study [92].

\section{Variable Measurement}

A total number of 32 items were used in this research to measure the variables. All of the variables were measured by - five point Likert scale (i.e. $1=$ Strongly Disagree, $2=$ Disagree, $3=$ Neutral, $4=$ Agree $\& 5=$ Strongly Agree) which were able to assist the researchers to perform arithmetical operations on the data collected from the respondents [84]. Besides, it is less confusing and able to result in a higher response rate and better quality of the collected data $[93,94]$.

\section{Results}

\section{Demographic Profile of the Respondents}

Table-3: Summarized Information of Demographic Profile

\begin{tabular}{|c|c|c|c|}
\hline Profile & Category & Frequency & Percentage (\%) \\
\hline Gender & $\begin{array}{l}\text { Female } \\
\text { Male }\end{array}$ & $\begin{array}{l}126 \\
133\end{array}$ & $\begin{array}{l}48.65 \\
51.35\end{array}$ \\
\hline Age Group & $\begin{array}{l}25 \text { or less } \\
26-30 \\
31-35 \\
36-40 \\
41-45 \\
45 \text { and above }\end{array}$ & $\begin{array}{l}77 \\
53 \\
36 \\
26 \\
25 \\
42\end{array}$ & $\begin{array}{c}29.73 \\
20.46 \\
13.90 \\
10.04 \\
9.65 \\
16.22\end{array}$ \\
\hline Marital Status & $\begin{array}{l}\text { Single } \\
\text { Married }\end{array}$ & $\begin{array}{l}145 \\
114 \\
\end{array}$ & $\begin{array}{l}55.98 \\
44.02 \\
\end{array}$ \\
\hline Visitation Pattern & $\begin{array}{l}\text { First time } \\
\text { Repeat }\end{array}$ & $\begin{array}{l}158 \\
101\end{array}$ & $\begin{array}{l}61.00 \\
39.00\end{array}$ \\
\hline Length of Stay & $\begin{array}{l}1-6 \\
7-12 \\
13-18 \\
\text { More than } 19\end{array}$ & $\begin{array}{c}186 \\
51 \\
7 \\
15 \\
\end{array}$ & $\begin{array}{l}71.81 \\
19.69 \\
2.70 \\
5.79\end{array}$ \\
\hline Purpose of Visit & $\begin{array}{l}\text { Business } \\
\text { Leisure/Holiday } \\
\text { Education } \\
\text { Others }\end{array}$ & $\begin{array}{c}37 \\
199 \\
23 \\
0\end{array}$ & $\begin{array}{c}14.29 \\
76.83 \\
8.88 \\
0.00 \\
\end{array}$ \\
\hline Geographical Origin & $\begin{array}{l}\text { Malaysia but other than Penang state } \\
\text { Asia (Exclude Malaysia) } \\
\text { Europe } \\
\text { Africa } \\
\text { South America } \\
\text { North America } \\
\text { Oceanic } \\
\text { Antarctic }\end{array}$ & $\begin{array}{c}129 \\
62 \\
28 \\
6 \\
8 \\
15 \\
11 \\
0\end{array}$ & $\begin{array}{l}49.81 \\
23.94 \\
10.81 \\
2.32 \\
3.09 \\
5.79 \\
4.25 \\
0.00\end{array}$ \\
\hline Who do you come with & $\begin{array}{l}\text { Family } \\
\text { Friends } \\
\text { Lover/Couple } \\
\text { Alone } \\
\text { Tour group } \\
\text { Others }\end{array}$ & $\begin{array}{c}50 \\
82 \\
44 \\
24 \\
58 \\
1\end{array}$ & $\begin{array}{c}19.31 \\
31.66 \\
16.99 \\
9.27 \\
22.39 \\
0.39\end{array}$ \\
\hline
\end{tabular}

The demographic profile of 259 valid respondents is presented in Table-3 above. 
Table-4: Statistics of Variables' Central Tendencies Measurement

\begin{tabular}{|c|c|c|c|c|}
\hline Variables & Items & $\mathbf{N}$ & Mean & Standard Deviation \\
\hline \multirow[t]{6}{*}{ Tangibles ( $\mathrm{T}$ ) } & T1 & 259 & 3.5521 & 1.2137 \\
\hline & $\mathrm{T} 2$ & & 3.6139 & 0.9792 \\
\hline & T3 & & 3.7954 & 0.9445 \\
\hline & $\mathrm{T} 4$ & & 3.7799 & 0.9075 \\
\hline & T5 & & 3.7529 & 0.9887 \\
\hline & T6 & & 3.6023 & 0.9845 \\
\hline \multirow[t]{5}{*}{ Reliability (R) } & R1 & 259 & 3.6564 & 0.8945 \\
\hline & $\mathrm{R} 2$ & & 3.7027 & 0.9727 \\
\hline & R3 & & 3.8185 & 0.9694 \\
\hline & R4 & & 3.6178 & 0.9174 \\
\hline & $\mathrm{R} 5$ & & 3.7104 & 0.9219 \\
\hline \multirow[t]{5}{*}{ Responsiveness (RP) } & RP1 & 259 & 3.6216 & 0.9461 \\
\hline & RP2 & & 3.6834 & 0.8627 \\
\hline & RP3 & & 3.6795 & 0.9930 \\
\hline & RP4 & & 3.6564 & 1.0276 \\
\hline & RP5 & & 3.7027 & 0.8894 \\
\hline \multirow[t]{5}{*}{ Assurance (A) } & $\mathrm{A} 1$ & 259 & 3.7645 & 0.8227 \\
\hline & $\mathrm{A} 2$ & & 3.8069 & 0.9072 \\
\hline & A3 & & 3.7915 & 0.8732 \\
\hline & A4 & & 3.7297 & 0.9130 \\
\hline & A5 & & 3.9266 & 0.9184 \\
\hline \multirow[t]{5}{*}{ Food Quality (FQ) } & FQ1 & 259 & 4.0695 & 0.8508 \\
\hline & FQ2 & & 3.9537 & 0.8792 \\
\hline & FQ3 & & 3.9923 & 0.8848 \\
\hline & FQ4 & & 3.9151 & 0.8982 \\
\hline & FQ5 & & 3.8340 & 0.9722 \\
\hline \multirow[t]{6}{*}{ Customer Satisfaction (CS) } & CS1 & 259 & 3.7297 & 0.9002 \\
\hline & CS2 & & 3.6911 & 0.9509 \\
\hline & CS3 & & 3.7683 & 0.8629 \\
\hline & CS4 & & 3.7683 & 0.9152 \\
\hline & CS5 & & 3.8069 & 0.9692 \\
\hline & CS6 & & 3.7992 & 0.8435 \\
\hline
\end{tabular}

The means and standard deviations for all the items in this research are depicted in Table-4 above. This indicates that majority of the items were answered by the respondents with the answers of "neutral" or "agree" except for FQ 1 which the respondents responded in the questionnaire with the answer of "agree" or "strongly agree".

On the other hand, the result of the analysis demonstrates that the standard deviations of all variables are ranged between 0.8227 to 1.2137 , which are represented by the variable of assurance $(\mathrm{A} 1)$ and tangibles $(\mathrm{T} 1)$ respectively. Both of them are the subvariables of service quality.

\section{Testing the Assumptions of Multivariate Analysis \\ Reliability Test}

Table-5: The Summary of Reliability Test

\begin{tabular}{|l|c|c|}
\hline \multicolumn{1}{|c|}{ Variables } & Number of Items & Cronbach's alpha value \\
\hline Tangibles (T) & 6 & 0.8892 \\
\hline Reliability (R) & 5 & 0.8449 \\
\hline Responsiveness (RP) & 5 & 0.8547 \\
\hline Assurance (A) & 5 & 0.8447 \\
\hline Food Quality (FQ) & 5 & 0.8443 \\
\hline Customer Satisfaction (CS) & 6 & 0.9083 \\
\hline
\end{tabular}

According to Sekaran [84], the Cronbach's alpha value of 0.7 and above is deemed to be reliable. Based on Table-5, all of the items in the variables have met the reliability test, as all the variables have the Cronbach's alpha value between 0.8443 to 0.9083 . This indicates that all items for each variable are reliable because Cronbach's alpha value for all items had exceeded 0.8 [84]. 


\section{Normality Test}

Table-6: Summarized Information of Normality Test

\begin{tabular}{|l|c|c|c|}
\hline Variables & Items & Skewness & Kurtosis \\
\hline \multirow{5}{*}{ Tangibles (T) } & T1 & -0.5551 & -0.6420 \\
& T2 & -0.3850 & -0.4461 \\
& T3 & -0.6930 & 0.2568 \\
& T4 & -0.8048 & 0.6336 \\
& T5 & -0.5786 & -0.2567 \\
& T6 & -0.3865 & -0.3780 \\
\hline & R1 & -0.5442 & -0.1464 \\
& R2 & -0.5453 & -0.0273 \\
Reliability (R) & R3 & -0.6322 & -0.0361 \\
& R4 & -0.6248 & 0.2700 \\
& R5 & -0.4398 & -0.1868 \\
\hline \multirow{5}{*}{ Responsiveness (RP) } & RP1 & -0.5344 & 0.0401 \\
& RP2 & -0.4342 & 0.2980 \\
& RP3 & -0.6379 & 0.0027 \\
& RP4 & -0.5244 & -0.2946 \\
& RP5 & -0.2784 & -0.3153 \\
\hline \multirow{5}{*}{ Assurance (A) } & A1 & -0.5487 & -0.0532 \\
& A2 & -0.5187 & -0.1446 \\
& A3 & -0.6018 & 0.3120 \\
& A4 & -0.5773 & 0.2799 \\
& A5 & -0.7312 & 0.2518 \\
\hline & FQ1 & -0.8945 & 0.6431 \\
& FQ2 & -0.4957 & -0.3171 \\
& FQ3 & -0.7969 & 0.4184 \\
& FQ4 & -0.7052 & 0.1867 \\
& FQ5 & -0.6051 & -0.0159 \\
\hline & CS1 & -0.6605 & 0.3091 \\
& CS2 & -0.6278 & 0.0476 \\
& CS3 & -0.4455 & -0.0047 \\
& CS4 & -0.5941 & 0.1746 \\
& CS5 & -0.6341 & -0.0707 \\
& CS6 & -0.4644 & -0.2460 \\
\hline & & & \\
& & & \\
& & &
\end{tabular}

Table-6 demonstrates the results of normality test for every item of each variable. Since every item has the value of skewness within the range of \pm 3 and the value of kurtosis falls within the range of \pm 10 , all items for each variable are normally distributed [95].

\section{Pearson's Correlation Analysis of Multicollinearity Problem}

Table-7: Coefficient Value of Pearson's Correlation Analysis

\begin{tabular}{|l|c|c|c|c|c|}
\hline \multicolumn{1}{|c|}{ Variables } & $\mathrm{T}$ & $\mathrm{R}$ & $\mathrm{RP}$ & $\mathrm{A}$ & $\mathrm{FQ}$ \\
\hline Tangibles (T) & 1.0000 & & & & \\
\hline Reliability (R) & $\begin{array}{c}0.5630 \\
\text { Sig. }<0.0001\end{array}$ & 1.0000 & & & \\
\hline Responsiveness (RP) & $\begin{array}{c}0.4846 \\
\text { Sig. }<0.0001\end{array}$ & $\begin{array}{c}0.6793 \\
\text { Sig. }<0.0001\end{array}$ & 1.0000 & & \\
\hline Assurance (A) & $\begin{array}{c}0.5358 \\
\text { Sig. }<0.0001\end{array}$ & $\begin{array}{c}0.6797 \\
\text { Sig. }<0.0001\end{array}$ & $\begin{array}{c}0.6725 \\
\text { Sig. }<0.0001\end{array}$ & 1.0000 & \\
\hline Food Quality (FQ) & $\begin{array}{c}0.4548 \\
\text { Sig. }<0.0001\end{array}$ & $\begin{array}{c}0.4716 \\
\text { Sig. }<0.0001\end{array}$ & $\begin{array}{c}0.4460 \\
\text { Sig. }<0.0001\end{array}$ & $\begin{array}{c}0.5156 \\
\text { Sig. }<0.0001\end{array}$ & 1.0000 \\
\hline
\end{tabular}

Based on Hair, Anderson, Tatham \& Blank [96], multicollinearity problem exists if the coefficient values among the independent variables exceed 0.9. From Table-7, the result of Pearson's correlation analysis depicts that the coefficient values among the independent variables ranges from 0.4460 to 0.6797 . Hence, it can be concluded that multicollinearity problem does not exist in this study as the highest coefficient value is merely 0.6797 , which is lower than the threshold level of 0.9 . Thus, the assumption of parametric test was fulfilled [97]. 
Multiple Linear Regression (MLR) Analysis

Table-8: Model Summary

\begin{tabular}{|c|c|c|c|c|}
\hline Root MSE & Dependent Mean & Coefficient Variation & R-square & Adjusted R-square \\
\hline 0.4418 & 3.7606 & 11.7483 & 0.6615 & 0.6548 \\
\hline
\end{tabular}

By referring to Table- 8 above, value of R-square scores at 0.6615 . This means that $66.15 \%$ of the variation of the dependent variable (customer satisfaction) can be explained by the independent variables consisting of food quality, reliability, tangibles, assurance and responsiveness.

Table-9: Analysis of Variance

\begin{tabular}{|l|c|c|c|c|c|}
\hline \multicolumn{1}{|c|}{ Source } & DF & Sum of Squares & Mean Square & F Value & Pr $>$ F \\
\hline Model & 5 & 96.4963 & 19.2993 & 98.87 & $<0.0001$ \\
\hline Error & 253 & 49.3843 & 0.1952 & & \\
\hline Corrected Total & 258 & 145.8805 & & & \\
\hline
\end{tabular}

It can be seen from the Table-9, that the F-value $(98.87)$ is large and the $p$-value $(<0.0001)$ is less than 0.05 . These indicate that at least one of the five independent variables can be used in modeling the dependent variable. Hence, model fit is achieved.

Table-10: Multiple Linear Regressions

\begin{tabular}{|l|c|c|c|c|c|c|}
\hline \multicolumn{1}{|c|}{ Variable } & Parameter Estimate & $\operatorname{Pr}>|t|$ & Standard Estimate & Tolerance & Variance Inflation & Hypotheses testing \\
\hline Intercept & -0.1396 & 0.4451 & 0 &. & 0 & \\
\hline Tangibles & -0.0681 & 0.1186 & -0.0732 & 0.6118 & 1.6347 & Not Supported \\
\hline Reliability & 0.3422 & $<.0001$ & 0.3345 & 0.4125 & 2.4243 & Supported \\
\hline Responsiveness & 0.0425 & 0.4363 & 0.0425 & 0.4508 & 2.2181 & Not Supported \\
\hline Assurance & 0.2359 & 0.0001 & 0.2187 & 0.4166 & 2.4002 & Supported \\
\hline Food Quality & 0.4633 & $<.0001$ & 0.4343 & 0.6753 & 1.4808 & Supported \\
\hline
\end{tabular}

According to Hair, Babin, Money \& Samouel [98], the relationship between the independent variables and the dependent variable will be significant and alternative hypothesis will be supported if the $p$-value of the independent variable is smaller than 0.05 . By referring to the Table 10, the hypotheses of $H_{2}(R), H_{4}(A)$ and $H_{5}(F Q)$ are supported as their $p$-values are less than 0.05 . On the contrary, the hypotheses of $\mathrm{H}_{1}(\mathrm{~T})$ and $\mathrm{H}_{3}(\mathrm{RP})$ are not supported as their $\mathrm{p}$-values are larger than 0.05 . Therefore, it can be concluded that reliability, assurance and food quality are significantly related to customer satisfaction, while tangibles and responsiveness are insignificantly related to customer satisfaction in this study. Therefore, the regression equation is formulated as:

$$
C S=-0.1396-0.0681(T)+0.3422(R)+0.0425(R P)+0.2359(A)+0.4633(F Q)
$$

This equation implies that all the independent variables possess a positive relationship with the customer satisfaction excluding tangibles (T). From the equation, we can conclude that customer satisfaction will decrease by 0.0681 , if tangibles increases by 1 provided other independent variables remain unchanged. Besides, if reliability, responsiveness, assurance and food quality increase by 1 respectively, the customer satisfaction will increase by $0.3422,0.0425,0.2359$ and 0.4633 respectively. In short, food quality was proved to be the dominant independent variable which has the strongest influence on customer satisfaction.

\section{Discussions OF MAJOR Findings}

\section{Tangibles}

Table-11: Finding on Tangibles

\begin{tabular}{|l|c|}
\hline \multicolumn{1}{|c|}{ Hypothesis } & Result \\
\hline $\begin{array}{l}\mathrm{H}_{1} \text { : There is a significant positive relationship between tangibles and customer } \\
\text { satisfaction of Penang tourists who patronizes Penang hawker centres. }\end{array}$ & $\begin{array}{c}\text { Not } \\
\text { Supported }\end{array}$ \\
\hline
\end{tabular}

Table-11 depicts that tangibles do not have significant positive relationship with the customer satisfaction of Penang tourists.

This result is not in line with the past researches conducted by Allan [99] and Bostanji [58] but consistent with the result of the study by Kaura et al., [57] which was not conducted in food service sector. Hence, this result can be considered as a new finding for the application of SERVQUAL model in food service sector context. In fact, the result of tangibles not significantly related to customer satisfaction in this study is justifiable, as this study was focusing on hawker centres rather than the fine dining restaurants. Thus, as compared to the fine dining, the customers of hawker centres may not expect to have a highly comfortable dining area and may not emphasize too much on the tangibles dimensions. 
Reliability

Table-12: Finding on Reliability

\begin{tabular}{|l|c|}
\hline \multicolumn{1}{|c|}{ Hypothesis } & Result \\
\hline $\begin{array}{l}|c| \\
\mathrm{H}_{2}: \text { There is a significant positive relationship between reliability and customer } \\
\text { satisfaction of Penang tourists who patronizes Penang hawker centres. }\end{array}$ & Supported \\
\hline
\end{tabular}

Table-12 displays that reliability is significantly and positively related with the customer satisfaction of Penang tourists. This result is in agreement with the past studies carried out in the food service sector by Teshome and Seyoum [61] and Namin [63]. Besides, this result is also consistent with the research results conducted in non-food service sectors such as banking sector [60], shipping sector [100], retail sector [101] and so on. This finding shows that the hawkers who serve customer precisely will be able to please the tourists who order food from them.

\section{Responsiveness}

Table-13: Finding on Responsiveness

\begin{tabular}{|l|c|}
\hline \multicolumn{1}{|c|}{ Hypothesis } & Result \\
\hline $\begin{array}{l}\mathrm{H}_{3}: \text { There is a significant positive relationship between responsiveness and } \\
\text { customer satisfaction of Penang tourists who patronizes Penang hawker centres. }\end{array}$ & Not Supported \\
\hline
\end{tabular}

The satisfaction level of Penang tourists cannot be predicted by the level of responsiveness as shown by the research result presented in Table-13. This outcome is in conformity with the study by Munusamy, Chelliah, and Hor [102] but inconsistent with the result the study conducted by Shanka [62], Ismail et al., [64] and Aghdaie and Faghani [14]. Responsiveness dimension does not have a significant positive relationship with the customer satisfaction probably because the target respondents are tourists. Majority of them may visit Penang only once in their life time. Hence, it is less likely that they will make complaints if they felt dissatisfied. Moreover, tourists might have expected that the hawkers will be busy and unable to provide prompt service as the hawker centres are perceived as a crowded dining area.

\section{Assurance}

Table-14: Finding on Assurance

\begin{tabular}{|l|c|}
\hline \multicolumn{1}{|c|}{ Hypothesis } & Result \\
\hline $\begin{array}{l}\mathrm{H}_{4}: \text { There is a significant positive relationship between assurance and customer } \\
\text { satisfaction of Penang tourists who patronizes Penang hawker centres. }\end{array}$ & Supported \\
\hline
\end{tabular}

Assurance significantly and positively affects the satisfaction level of Penang tourists as depicted in Table-14. This result is conflicting with the study conducted by Zhang, Xie, Huang, and He [103] but is congruent with the research results concluded by Omar et al., [66]. The finding indicates that courteous, friendly and polite hawkers are able to delight the tourists who patronize their stalls.

\section{Food Quality}

Table-15: Finding on Food Quality

\begin{tabular}{|l|c|}
\hline \multicolumn{1}{|c|}{ Hypothesis } & Result \\
\hline $\begin{array}{l}\mathrm{H}_{5}: \text { There is a significant positive relationship between food quality and customer } \\
\text { satisfaction of Penang tourists who patronizes Penang hawker centres. }\end{array}$ & Supported \\
\hline
\end{tabular}

Food quality has a positive and significant relationship with customer satisfaction of Penang tourists according to the research result presented in Table-15. Besides, food quality is found to be the most influential variable in affecting customer satisfaction in this study. This result is conforming to the past researches conducted by Ma, Qu, Njite, and Chen [104] and Ryu et al., [16]. Besides, there are also various past studies confirming the significance of food quality in affecting customer satisfaction [72, 71]. This finding shows that the tasty foods are the main antecedent of Penang tourists' satisfaction.

\section{Implications of the Study Managerial Implications}

This study concludes that Food quality has the largest impact in influencing the satisfaction level of Penang tourists. Therefore, Penang State Government should emphasize on improving the quality of Penang street foods during the policy setting process. More policies that assist in improving deliciousness, freshness, smell and unique taste of Penang street food should be framed. Besides that, the second and third most significant predictors of customer satisfaction are proved to be the reliability and assurance. Thus, Penang State Government may conduct workshops to train the hawkers to be able to serve their customers timely, accurately, politely, courteous and friendly. Last but not the least, as tangibles and responsiveness do not have significant relationship 
with customer satisfaction of Penang tourists, Penang State Government should prioritize in considering other significant variables during policy setting due to the scarce time and resources.

\section{Theoretical Implications}

This research has confirmed the positive relationship between the food and service quality with satisfaction of customers particularly diners. This study has adopted and refined SERVQUAL model developed by Parasuraman et al., [35] which has been criticized as failed to take into consideration of food quality when this model is applied in food service sector [6, 7]. However, the outcome of this study has shown that food quality has more significant influence on customer satisfaction than service quality. Hence, in the future, other academicians or researchers may apply this research framework in their research on the food service area. Besides, there are many past studies conducted to investigate customer satisfaction in various sectors. However, for food service sector, similar researches were conducted by focusing on restaurants instead of hawker centres [15, 16]. Hence, there has been a doubt of whether SERVQUAL model is applicable in hawker centres. However, the result of this study has shown that the R-square value is 0.6615 and the $p$-value of the model is less than 0.05; thus the SERVQUAL model in addressing customer satisfaction level in hawker centres has been validated. Furthermore, in terms of geographical location, there are only a few studies conducted on Penang, Malaysia food service sector [11, 12]. Thus this study is contributable as it proved that SERVQUAL model is workable in Malaysia food service sector. As there are limited literatures on the Penang hawker centers and street food, this study also enriches the foresaid literatures.

\section{Limitations of the Study and Recommendations for Future Research}

Due to time and budget constraints, cross-sectional approach was applied to conduct this research. Hence, the data was collected in one time [77]. The collected data and analyzed results may be only applicable for current situation and become plausible and irrelevant in the future [105]. Hence, the future researchers are suggested to conduct longitudinal study in the similar context which will take into consideration of changes of the perception of the target respondents over time [106].

Apart from this, due to cost effective reason, survey questionnaire has been utilized in this research for data collection [107]. Hence, data collected might have bias due to the possibility of none of the questionnaire items fit with respondent's perceptions and thought. Thus, future researchers are recommended to apply interview as the data collection method. This will enable the researchers to prevent the respondents felt irritated when answering the questions by allowing them to "speak in their own voice and express their own thoughts and feelings" [108]. Moreover, open-ended questions asked during the interview will be able to minimize bias that arise from fixed alternatives given which do not fit with respondent's thought [109].

Last but not least, based on the result of MLR analysis, the value of R-square 0.6615 indicates that $33.85 \%$ of the variation of the customer satisfaction is affected by other antecedents that are not tested in this study such as perceived quality, price fairness and others which were proved by various literatures as having significant positive relationship with customer satisfaction [110, 12]. Future researchers are recommended to develop a new conceptual model which takes into consideration of SERVQUAL, food quality, perceived value, price fairness and other variables to further investigate the antecedents of customer satisfaction. Hence, model with a higher R-square value might be produced to better address the customer satisfaction of hawker centres as well as other segments of food service sector.

\section{CONCLUSION}

In a nutshell, all variables except tangibles and responsiveness played their significant roles in positively affecting the customer satisfaction of Penang tourists who patronize the Penang hawker centres. Based on the result of this study, food quality was proved to be the most influential variable affecting customer satisfaction in food service sector followed by reliability and assurance. Few justifications were given to explain why hypotheses of tangibles and responsiveness were not supported. In other words, the objectives of this study have been achieved which is to examine the influence of service and food quality on customer satisfaction in the context of food service industry in Penang, particularly in the Penang hawker centres.

\section{REFERENCES}

1. Goldberg, L. (2013, Feb 22). Asia's 10 greatest street food cities. CNN Travel. Retrieved from http://travel.cnn.com/explorations/eat/asia-street-food-cities-612721/

2. Time Magazine. (2004, Nov 22). Best Street Food. Time Magazine, 164 (20). Retrieved from http://content.time.com/time/magazine/asia/0,9263,501041122,00.html

3. George, S. (2015). The tourists keep coming! Penang Monthly. Retrieved 17 February from http://penangmonthly.com/article.aspx?pageid=3934\&name=the_tourists_keep_coming

4. Angelova, B., \& Zekiri, J. (2011). Measuring customer satisfaction with service quality using American customer satisfaction model (ACSI Model). International Journal of Academic Research in Business and Social Sciences, 1(3), 232-258.

5. Agyapong, G. K. O. (2011). The effect of service quality on customer satisfaction in the utility industry - A case of Vodafone (Ghana). International Journal of Business and Management, 6(5), 203-210. 
6. Namkung, Y., \& Jang, S. (2007). Does food quality really matter in restaurants? Its impact on consumer satisfaction and behavioral intentions. Journal of Hospitality and Tourism Research, 31(3), 387-410.

7. Tan, Q., Oriade, A., \& Fallon, P. (2014). Service quality and customer satisfaction in Chinese fast food sector: A proposal for CFFRSERV. An International Journal of Akdeniz University Tourism Faculty, 2(1), 30-53.

8. Salman, A., \& Hasim, M. (2012). Factors and competitiveness of Malaysia as a tourist destination: A study of outbound Middle East tourists. Asian Social Science, 8(12), 48-54.

9. Kuo, C., Chung, M., \& Kuo, F. (2012). To explore Taiwanese night markets culture and tourism experience and behavior. Procedia - Social and Behavioral Sciences, 40, 434-440.

10. Sharath, A. M. (2016). An economic analysis of street food vendors with special reference to Durgigudi street, Shivamogga city. CLEAR International Journal of Research in Commerce \& Management, 7(7), 84-89.

11. Zainol, N., Rozali, A. R. A., Razali, M. A., Tazijan, F. N., \& Ngelambong, A. A. (2015). Service quality measurement in Kopitiam Seberang Jaya, Pulau Pinang. Journal of Applied Environmental and Biological Sciences, 5(6S), 100-105.

12. Moorthy, K., Chee, L. E., Yi, O. C., Ying, O. S., Woen, O. Y., \& Wei, T. M. (2016). Customer loyalty to newly opened cafés and restaurants in Malaysia. Journal of Foodservice Business Research, 1-17.

13. Saleh, F., \& Ryan, C. (1991). Analysing service quality in the hospitality industry using the SERVQUAL model. The Service Industries Journal, 11(3), 324-345.

14. Aghdaie, S. F. A., \& Faghani, F. (2012). Mobile banking service quality and customer satisfaction (application of SERVQUAL model). International Journal of Management and Business Research, 2(4), 351-361.

15. Polyorat, K., \& Sophonsiri, S. (2010). The influence of service quality dimensions on customer satisfaction and customer loyalty in the chain restaurant context: A Thai case. Journal of Global Business \& Technology, 6(2), 64-76.

16. Ryu, K., \& Han, H. (2009). Influence of the quality of food, service, and physical environment on customer satisfaction and behavioral intention in quick-casual restaurants: Moderating role of perceived price. Journal of Hospitality \& Tourism Research, 34(3), 310-329.

17. Clark, M. A., \& Wood, R. C. (1999). Consumer loyalty in the restaurant industry: A preliminary exploration of the issues. British Food Journal, 101(4), 317-327.

18. Stevens, P., Knutson, B., \& Patton, M. (1995). DINESERV: A tool for measuring service quality in restaurants. Cornell Hotel and Restaurant Administration Quarterly, 36(2), 56-60.

19. Bougoure, U., \& Neu, M. (2010). Service quality in the Malaysian fast food industry: An examination using DINESERV. Services Marketing Quarterly, 31(2), 194-212.

20. Markovic, S., Komsic, J., \& Stifanic, M. (2013). Measuring service quality in city restaurant settings using DINESERV scale. Recent Advances in Business Management and Marketing. Retrieved from http://docplayer.net/18224640-Measuring-servicequality-in-city-restaurant-settings-using-dineserv-scale.html

21. Mengi, P. (2009). Customer satisfaction with service quality: An empirical study of public and private sector banks. IUP Journal of Management Research, 8(9), 7-17.

22. Phan, C. A., \& Nham, P. T. (2015). Impact of service quality on customer satisfaction of automated teller machine service: Case study of a private commercial joint stock bank in Vietnam. Verslas: Teorija Ir Praktika, 16(3), 280-289.

23. Bujisic, M., Hutchinson, J., \& Parsa, H. (2014). The effects of restaurant quality attributes on customer behavioral intentions. International Journal of Contemporary Hospitality Management, 26(8), 1270-1291.

24. Agyei, P. M., \& Kilika, J. M. (2013). The relationship between service quality and customer loyalty in the Kenyan mobile telecommunication service industry. European Journal of Business and Management, 5(23), 26-36.

25. Albarq, A. N. (2013). Applying a SERVQUAL model to measure the impact of service quality on customer loyalty among local Saudi banks in Riyadh. American Journal of Industrial and Business Management, 3, 700-707.

26. Eshghi, A., Roy, S. K., \& Ganguli, S. (2008). Service quality and customer satisfaction: An empirical investigation in Indian mobile telecommunications services. Marketing Management Journal, 18(2), 119-144.

27. Horsu, E. N., \& Yeboah, S. T. (2015). Influence of service quality on customer satisfaction: A study of minicab taxi services in Cape Coast, Ghana. International Journal of Economics, Commerce and Management, 3(5), 1451-1464.

28. Singh, S. (2016). Assessment of passenger satisfaction with public bus transport services: A case study of Lucknow City (India). Studies in Business and Economics, 11(3), 107-128.

29. Thai, V. (2015). The impact of port service quality on customer satisfaction: The case of Singapore. Maritime Economics \& Logistics, 1-18.

30. Ahmad, A. A. (2015). The effect of service and food quality on customer satisfaction and hence customer retention. Asian Social Science, 11(23), 129-139.

31. Liang, X., \& Zhang, S. (2009). Investigation of customer satisfaction in student food service. International Journal of Quality and Service Sciences, 1(1), 113-124.

32. Zhang, Z., Zhang, Z., \& Law, R. (2014). Relative importance and combined effects of attributes on customer satisfaction. The Service Industries Journal, 34(6), 550-566.

33. Koshki, N., Esmaeilpour, H., \& Ardestani, A. S. (2014). The study on the effects of environmental quality, food and restaurant services on mental image of the restaurant, customer perceived value, customer satisfaction and customer behavioral intentions: Case study of Boroujerd's restaurants. Kuwait Chapter of Arabian Journal of Business and Management Review, 3(10), 261272. 
34. Parasuraman, A., Zeithaml, V. A., \& Berry, L. L. (1985). A conceptual model of service quality and its implications for future research. Journal of Marketing, 49(4), 41-50.

35. Parasuraman, A., Zeithaml, V. A., \& Berry, L. L. (1988). SERVQUAL: A multiple-item scale for measuring consumer perceptions of service quality. Journal of Retailing, 64(1), 12-40.

36. Brown, S. W., \& Swartz, T. A. (1989). A gap analysis of professional service quality. Journal of Marketing, 53(2), 92-98.

37. Carman, J. M. (1990). Consumer perceptions of service quality: An assessment of the SERVQUAL dimensions. Journal of Retailing, 66(1), 33-53.

38. Cronin, J. J., \& Taylor, S. A. (1992). Measuring service quality: A reexamination and extension. Journal of Marketing, 56(3), 5568.

39. Parasuraman, A., Zeithaml, V. A., \& Berry, L.L. (1991). Refinement and reassessment of the SERVQUAL Scale. Journal of Retailing, 67(4), 420-450.

40. Parasuraman, A., Zeithaml, V. A., \& Berry, L. L. (1993). Research note: More on improving service quality measurement. Journal of Retailing, 69(1), 140-147.

41. Mehta, S. C., \& Durvasula, S. (1998). Relationships between SERVQUAL dimensions and organizational performance in the case of a business-to-business service. Journal of Business \& Industrial Marketing, 13(1), 40-53.

42. Lam, T., \& Zhang, H. (1999). Service quality of travel agents: The case of travel agents in Hong Kong. Tourism Management, 20(3), 341-349.

43. Frochot, I., \& Hughes, H. (2000). HISTOQUAL: The development of a historic houses assessment scale. Tourism management, 21(2), 157-167.

44. Yoo, B., \& Donthu, N. (2001). Developing a scale to measure the perceived quality of internet shopping sites (SITEQUAL). Quarterly Journal of Electronic Commerce, 2(1), 31-47.

45. Barnes, S. J., \& Vidgen, R. (2001). An evaluation of cyber-bookshops: the WebQual method. International journal of electronic commerce, 6(1), 11-30.

46. Cook, C., Heath, F., \& Thompson, B. (2001). Users' hierarchical perspectives on library service quality: A "LibQUAL+" study. College and Research Libraries, 62(2), 147-153.

47. Khan, M. (2003). ECOSERV: Ecotourists' quality expectations. Annals of Tourism Research, 30(1), 109-124.

48. Parasuraman, A., Zeithaml, V. A., \& Malhotra, A. (2005). ES-QUAL: a multiple-item scale for assessing electronic service quality. Journal of service research, 7(3), 213-233.

49. Keith, N. K., \& Simmers, C. S. (2013). Measuring hotel service quality perceptions: The disparity between comment cards and LODGSERV. Academy of Marketing Studies Journal, 17(2), 119-131.

50. Ali, F., Dey, B., \& Filieri, R. (2015). An assessment of service quality and resulting customer satisfaction in Pakistan International Airlines. International Journal of Quality \& Reliability Management, 32(5), 486-502.

51. Swimberghe, K. R., \& Wooldridge, B. R. (2014). Drivers of customer relationships in quick-service restaurants. Cornell Hospitality Quarterly, 55(4), 354-364.

52. Lai, I. K. W. (2015). The roles of value, satisfaction, and commitment in the effect of service quality on customer loyalty in Hong Kong-style tea restaurants. Cornell Hospitality Quarterly, 56(1), 118-138.

53. Pizam, A., Shapoval, V., \& Ellis, T. (2016). Customer satisfaction and its measurement in hospitality enterprises: A revisit and update. International Journal of Contemporary Hospitality Management, 28(1), 2-35.

54. Ara, A. (2016). Guest satisfaction in hotels of Kashmir: The perception of foreign tourists. International Journal of Research in Commerce and Management, 7(4), 88-93.

55. Sulek, J. M., \& Hensley, R. L. (2004). The relative importance of food, atmosphere, and fairness of wait: The case of a fullservice restaurant. Cornell Hospitality Quarterly, 45(3), 235-247.

56. Law, A. K. Y., Hui, Y. V., \& Zhao, X. (2004). Modelling repurchase frequency and customer satisfaction for fast food outlets. International Journal of Quality \& Reliability Management, 21(5), 545-563.

57. Kaura, V., Durga, P. C. S., C., \& Sharma, S. (2015). Service quality, service convenience, price and fairness, customer loyalty, and the mediating role of customer satisfaction. International Journal of Bank Marketing, 33(4), 404-422.

58. Bostanji, G. M. A. (2013). The impact of service quality on customers loyalty: A study on five stars hotel's customers in Riyadh, KSA. European Journal of Business and Management, 5(31), 230-240.

59. Kawpong, P., \& Suvenus, S. (2010). The influence of service quality dimensions on customer satisfaction and customer loyalty in the chain restaurant context: A Thai case. Journal of Global Business and Technology, 6(2), 64-76.

60. Dauda, S. Y., \& Lee, J. (2016). Quality of service and customer satisfaction: A conjoint analysis for the Nigerian bank customers. International Journal of Bank Marketing, 34(6), 841-867.

61. Teshome, T., \& Seyoum, Y. (2014). Assessment of satisfaction level among guests of Wolaita Sodo City. International Journal of Research in Commerce \& Management, 5(12), 90-97.

62. Shanka, M. S. (2012). Bank service quality, customer satisfaction and loyalty in Ethiopian banking sector. Journal of Business Administration and Management Sciences, 1(1), 1-9.

63. Namin, A. (2017). Revisiting customers' perception of service quality in fast food restaurants. Journal of Retailing and Consumer Services, 34, 70-81.

64. Ismail, A., Zaki, H. O., \& Rose, I. R. (2016). Interlinkages between service quality, customer satisfaction and customer loyalty in Malaysia: A case study of armed forces medical organizations. Malaysian Journal of Society and Space, 12(7), 47-59. 
65. Leong, L., Hew, T., Lee, V., \& Ooi, K. (2015). An SEM-artificial-neural-network analysis of the relationships between SERVPERF, customer satisfaction and loyalty among low-cost and full-service airline. Expert Systems with Applications, 42(19), 6620-6634.

66. Omar, M. S., Ariffin, H. F., \& Ahmad, R. (2016). Service quality, customers' satisfaction and the moderating effects of gender: A study of Arabic restaurants. Procedia - Social and Behavioral Sciences, 224, 384-392.

67. Anjum, U., Aftab, J., Sultan, Q., \& Ahmed, M. (2016). Factors affecting the service quality and customer satisfaction in telecom industry of Pakistan. International Journal of Management, Accounting and Economics, 3(9), 509-520.

68. Koo, L. C., Tao, F. K. C., \& Yeung, J. H. C. (1999). Preferential segmentation of restaurant attributes through conjoint analysis. International Journal of Contemporary Hospitality Management, 11(5), 242-253.

69. Pei, K. J., \& Ayub, A. B. (2015). Measuring customer satisfaction towards cafeteria services in primary health care setting: A cross-section study among patients and health care providers in Bintulu, Sarawak. Open Access Library Journal, 2(4), 1-11.

70. Raajpoot, N. A. (2002). TANGSERV: A multiple item scale for measuring tangible quality in foodservice industry. Journal of Foodservice Business Research, 5(2), 109-127.

71. Ramanathan, R., Di, Y., \& Ramanathan, U. (2016). Moderating roles of customer characteristics on the link between service factors and satisfaction in a buffet restaurant. Benchmarking: An International Journal, 23(2), 469-486.

72. Hanaysha, J. (2016). Testing the effects of food quality, price fairness, and physical environment on customer satisfaction in fast food restaurant industry. Journal of Asian Business Strategy, 6(2), 31-40.

73. Jihye Jeong \& Sunhee Seo, (2014). Importance of satisfaction with food for older adults' quality of life. British Food Journal, 116 (8), 1276-1290. https://doi.org/10.1108/BFJ-01-2013-0019.

74. Taeshik Gong \& Youjae Yi (2018). The effect of service quality on customer satisfaction, loyalty, and happiness in five Asian countries. Psychology \& Marketing, https://doi.org/10.1002/mar.21096.

75. Ryu, K., Lee, H., \& Kim, W. G. W. (2012). The influence of the quality of the physical environment, food, and service on restaurant image, customer perceived value, customer satisfaction, and behavioral intentions. International Journal of Contemporary Hospitality Management, 24(2), 200-223.

76. Bahrick, H. P., Bahrick, P. O., \& Wittlinger, R. P. (1975). Fifty years of memory for names and faces: A cross-sectional approach. Journal of Experimental Psychology, 104(1), 54-75.

77. Mann, C. J. (2003). Observational research methods. Research design II: Cohort, cross sectional, and case-control studies. Emergency Medicine Journal, 20(1), 54-60.

78. Burns, A. C., \& Bush, R. F. (2000). Marketing Research (5th ed.). Pearson International Edition.

79. Yasseen, Y. (2011). Outsourcing the internal audit function: A survey of the South African public and private sectors. University of the Witwatersrand.

80. Akbayrak, B. (2000). A Comparison of Two Data Collecting Methods: Interviews and Questionnaires. Hacettepe University.

81. Muijs, D. (2004). Doing quantitative research in education with SPSS. London: SAGE publications.

82. Mitchell, M. L., \& Jolley, J. M. (2012). Research Design Explained (8th ed.). Belmone, CA: Cengage Learning.

83. Molla, A., \& Licker, P. S. (2005). Ecommerce adoption in developing countries: A model and instrument. Information \& Management, 42(6), 877-899.

84. Sekaran, U. (2003). Research methods for business: A skill building approach (4th ed.). New York: John Wiley \& Sons, Inc.

85. Saunders, M., Lewis, P., \& Thornhill, A. (2012). Research methods for business students (6th ed.). Harlow, England: Pearson Education Limited.

86. Cochran, W. G. (1966). Sampling techniques (2nd ed.). New York: John Wiley \& Sons Inc.

87. Lucas, S. R. (2016). Where the rubber meets the road: Probability and nonprobability moments in experiment, interview, archival, administrative, and ethnographic data collection. Socius: Sociological Research for a Dynamic World, 2(0), 1-24.

88. Uprichard, E. (2013). Sampling: Bridging probability and non-probability designs. International Journal of Social Research Methodology, 16(1), 1-11.

89. Karmel, T. S., \& Jain, M. (1987). Comparison of purposive and random sampling schemes for estimating capital expenditure. Journal of the American Statistical Association, 82(97), 52-57.

90. Sekaran, U. (1992). Research methods for business (2nd ed.). Singapore: John Wiley \& Sonc Inc.

91. Etikan, I. (2016). Comparison of convenience sampling and purposive sampling. American Journal of Theoretical and Applied Statistics, 5(1), 1-4.

92. Hinkin, T. (1995). A review of scale development practices in the study of organizations. Journal of Management, 21(5), 967988.

93. Babakus, E., \& Mangold, W. G. (1992). Adapting the SERVQUAL scale to hospital services: An empirical investigation. Health Services Research, 26(6), 768-786.

94. Zikmund, W. G. (2003). Business research methods (7th ed.). Thomson South-Western.

95. Kline, R. B. (2005). Principles and practice of structural equation modeling (2nd ed.). New York: Guilford Press.

96. Hair, J. F., Anderson, R., Tatham, R., \& Blank, W. (1998). Multivariate data analysis (5th ed.). New Jersey: Prentice-Hall.

97. Norman, G. (2010). Likert scales, levels of measurement and the "laws" of statistics. Advances in Health Sciences Education, 15(5), 625-632.

98. Hair, J. F., Babin, B., Money, A. H., \& Samouel, P. (2003). Essentials of business research methods (1st ed.). New Jersey: John Wiley \& Sons, Inc. 
99. Allan, M. M. (2016). The relationship between service quality and customer satisfaction and retention in Ghana's luxury hotels. IUP Journal of Marketing Management, 15(4), 60-83.

100. Yuen, K. F., \& Thai, V. V. (2015). Service quality and customer satisfaction in liner shipping. International Journal of Quality and Service Sciences, 7(2/3), 170-183.

101. Mahfooz, Y. (2014). Relationship between service quality and customer satisfaction in hypermarkets of Saudi Arabia. International Journal of Marketing Studies, 6(4), 10-22.

102. Munusamy, J., Chelliah, S., \& Hor, W. M. (2010). Service quality delivery and its impact on customer satisfaction in the banking sector in Malaysia. International Journal of Innovation, Management and Technology, 1(4), 398-404.

103. Zhang, M., Xie, Y., Huang, L., \& He, Z. (2013). Service quality evaluation of car rental industry in China. International Journal of Quality \& Reliability Management, 31(1), 82-102.

104. Ma, J., Qu, H., Njite, D., \& Chen, S. (2011). Western and Asian customers' perception towards Chinese restaurants in the United States. Journal of Quality Assurance in Hospitality \& Tourism, 12(2), 121-139.

105. Carlson, M. D. A., \& Morrison, R. S. (2009). Study design, precision, and validity in observational studies. Journal of Palliative Medicine, 12(1), 77-82.

106. Caruana, E. J., Roman, M., Hernández-Sánchez, J., \& Solli, P. (2015). Longitudinal studies. Journal of Thoracic Disease, 7(11), 537-540.

107. McClelland, S. B. (1994). Training needs assessment data-gathering methods: Part 1, survey questionnaires. Journal of European Industrial Training, 18(1), 22-26.

108. Berg, B. L. (2007). Qualitative research methods for the social sciences. London: Pearson.

109. Reja, U., Manfreda, K. L., Hlebec, V., \& Vehovar, V. (2003). Open-ended vs. close-ended questions in web questionnaires. Developments in Applied Statistics, 19(1), 160-177.

110. Herrmann, A., Xia, L., Monroe, K., \& Huber, F. (2007). The influence of price fairness on customer satisfaction: An empirical test in the context of automobile purchases. Journal of Product \& Brand Management, 16(1), 49-58. 